\title{
PELATIHAN PENGURANGAN RISIKO BENCANA BAGI GURU TAMAN KANAK-KANAK DI KOTA BANDUNG
}

\author{
Euis Kurniati ${ }^{1}$, Vina Adriany ${ }^{2}$ Mirawati $^{3}$, Ina Winangsih ${ }^{4}$, Ridha Marissa El-Siera $^{5}$ \\ 1,2, 3, 4,5 Universitas Pendidikan Indonesia
}

\begin{abstract}
Flood disasters that often occur in Bandung have many disadvantages, especially for early childhood. Previous studies have shown children to be vulnerable and dependent on adults for disaster. This paper describes training related to kindergarten teachers with the aim to instill awareness of the importance of disaster preparedness in early childhood education institutions. The method used was participatory action research and involved 24 teachers from 12 kindergarten institutions from Dayeuhkolot Bandung as areas that were frequently affected by floods as participants. The results of this study are expected to be a means and input for policy makers and educators in increasing disaster preparedness.
\end{abstract}

Keyword: kindergarten teacher training, disaster risk reduction, early childhood preparedness

\begin{abstract}
Abstrak: Bencana banjir yang sering terjadi di Bandung memiliki banyak kerugian terutama bagi anak usia dini. Penelitian-penelitian sebelumnya menunjukkan anak sebagai seorang yang rentan dan memiliki kebergantungan pada orang dewasa dalam kebencanaan. Artikel menggambarkan terkait pelatihan bagi guru TK dengan tujuan untuk menanamkan kesadaran akan pentingnya kesiapsiagaan bencana di lembaga pendidikan anak usia dini. Metode yang digunakan adalah participatory action research dan melibatkan 24 orang guru dari 12 lembaga TK yang berasal dari kecamatan Dayeuhkolot Bandung sebagai wilayah yang sering terdampak dalam bencana banjir sebagai partisipan. Adapun hasil dari kajian ini diharapkan dapat menjadi sarana dan masukkan bagi pemangku kebijakan dan pendidik dalam meningkatkan kesiapsiagaan terhadap bencana.
\end{abstract}

Kata Kunci: Pelatihan Guru TK, pengurangan risiko bencana, kesiapsiagaan anak usia dini

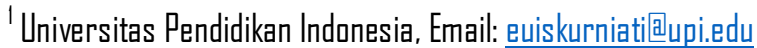

${ }^{2}$ Universitas Pendidikan Indonesia, Email: vina国upi.edu

${ }^{3}$ Universitas Pendidikan Indonesia, Email: mirawati国upi.edu

${ }^{4}$ Universitas Pendidikan Indanesia, Email: ina国upi.edu

${ }^{5}$ Universitas Pendidikan Indanesia, Email: ridhamarissa国upi.edu
} 


\section{PENDAHULUAN}

Kondisi alam dan sejarah kebencanaan di Indonesia, membuat masyarakat Indonesia harus selalu siaga. Di wilayah Kota Bandung sendiri, berdasarkan data pada tahun 2018 terjadi beberapa kali kejadian banjir yang melanda Bandung, beberapa diantaranya yaitu banjir di sejumlah titik di daerah Bandung bagian timur khususnya di daerah Dayeuhkolot, jebolnya tanggul Sungai Cironggeng, banjir bandang akibat tanggul Sungai Cipamokolan jebol berdampak pada banjir di Cicaheum. meluapnya Sungai Cicabe dan Cileuweung akibat hujan dari Bandung bagian utara dan masih banyak lagi kejadian banjir di wilayah Bandung lainnya. Hal tersebut merupakan bencana yang perlu diwaspadai dan disikapi dengan kesiapsiagaan yang baik oleh semua individu termasuk anak usia dini, namun sayangnya hal tersebut belum nampak dalam fakta di lapangan.

Secara khusus dalam pendidikan, kesadaran guru terhadap bencana haruslah menjadi sebuah kompetensi standar (Haynes, dkk., 2017). Dalam hal perilaku atau kesadaran masyarakat terhadap lingkungan, masih banyak masyarakat yang belum atau kurang menyadari bahwa perilaku sehari-hari atau kegiatan yang dilakukannya dapat merugikan orang lain, baik di daerah tersebut maupun di daerah lain. Bencana alam memiliki dampak negatif yang menyebabkan keseimbangan perkembangan seseorang terganggu menjadi ketidakseimbangan pada aspek perkembangan seseorang (Peek, Abramson, S.Cox, Fothergill, \& Tobin, 2018, hlm. 244).

Peek, dkk (2018) juga menyatakan bahwa ketidakseimbangan aspek pada perkembangan terutama dirasakan oleh anak sebagai dampak dari bencana dpat dirasakan terutama pada anak. Ketidakseimbangan aspek perkembangan pada anak dapat dialami anak seperti stress, depresi, dan perasaan lainnya. Aspek perkembangan anak dapat diperkuat pada seluruh anak untuk menanamkan kesiapsiagaan anak dalam menghadapi bencana.

Kemampuan kesiapsiagaan anak untuk menghadapi bencana belum menjadi prioritas di lingkup pendidikan anak usia dini. Pada praktiknya, anakanak dianggap sebagai seseorang yang rapuh, rentan, dan masih berkegantungan pada bantuan orang dewasa (Thomas, Phillips, Lovekamp, \& Fothergill, 2013; Aghaei, Seyedin, \& Sanaeinasab, 2018) yang tidak memiliki kemampuan dalam kesiapsiagaan menghadapi bencana. Namun kemampuan kesiapsiagaan anak sebenarnya dapat dikembangkan dengan adanya studi kebencanaan dan pendidikan dari orang dewasa sedini mungkin pada lingkup pendidikan anak usia dini.

Konvensi $\quad$ PBB 1989 menunjukkan bahwa pengurangan risiko bencana oleh orang dewasa pada anak usia dini merupakan upaya dalam melindungi hak- hak anak dan kesejahteraan anak (Peek, Abramson, S.Cox, Fothergill, \& Tobin, 2018). Pengurangan Risiko Bencana pada anak menunjukkan bahwa pendekatan yang berpusat pada anak merupakan prioritas dalam upaya pengurangan risiko bencana. Pengurangan risiko bencana pada anak usia dini dapat dilakukan di PAUD dengan berpusat pada anak melalui kegiatan-kegiatan yang melibatkan aktivitas yang dilakukan anak.

Berdasarkan kondisi yang telah di uraikan sebelumnya, kemampuan kesiapsiagaan anak untuk menghadapi bencana belum menjadi prioritas di lingkup pendidikan anak usia dini. Pada praktik di lapangan anak-anak dianggap sebagai seseorang yang rapuh, rentan, dan masih sangat bergantung pada bantuan orang dewasa yang dianggap tidak memiliki kemampuan dalam kesiapsiagaan menghadapi bencana. 
Permasalahan di atas salah satunya dikarenakan masih minimnya pemahaman dan kesadaran dari pendidik PAUD dalam hal mitigasi bencana di jenjang PAUD. Salah satu solusi yang dilakukan dalam kajian ini yaitu dengan memberikan pelatihan kepada guru TK terkait pengurangan risiko bencana di jenjang PAUD. Pelatihan tersebut diharapkan dapat meningkatkan kesiapsiagaan guru dan mendorong guru untuk menerapkan pendidikan kesiapsiagaan bagi anak-anak di lingkungannya, sehingga dapat berkontribusi terhadap pengurangan risiko bencana alam, khususnya pada jenjang pendidikan anak usia dini.

\section{TINJUAN PUSTAKA}

\section{Risiko Bencana}

United Nations Office for Disaster Risk Reduction (UNISDR) (2009) menyatakan bahwa fenomena alam yang memberikan dampak kerugian pada berbagai aspek kehidupan termasuk aspek ekonomi, sosial, infrastruktur, dan lain-lain disebut sebagai bencana alam. Berdasarkan Undang-Undang No. 24 Tahun 2007 menyatakan bahwa Bencana merupakan suatu peristiwa atau rangkaian peristiwa yang mengancam dan mengganggu kehidupan dan penghidupan masyarakat yang disebabkan, baik oleh faktor alam dan atau faktor non-alam maupun faktor manusia sehingga mengakibatkan timbulnya korban jiwa manusia, kerusakan lingkungan, kerugian harta benda, dan dampak psikologis. ASEAN Disaster Reduction and Response Network (ASDRRN, 2010) menyatakan bahwa terdapat 3 unsur yang dijadikan sebagai ukuran tingginya potensi bencana (risiko bencana) yaitu ancaman, kerentanan, dan kapasitas. Untuk memperkecil suatu risiko yang diakibatkan oleh bencana alam, maka perlunya peningkayan kapasitas dari warga yang memiliki kemungkinan terdampak bencana yang diformulasikan dalam rumus: $\mathrm{R}=(\mathrm{V} * \mathrm{H}) / \mathrm{C}$.

Risiko ( $\mathrm{R}=$ Risk), merupakan potensi kerugian yang diakbatkan oleh bencana terhadap kehidupan manusia secara materil, psikis, status kesehatan, aset dan layanan, yang dapat terjadi pada masyarakat selama jangka waktu tertentu di masa mendatang. Kerentanan (V=Vulnerability), merupakan suatu kondisi kecenderungan terdampak rusaknya suatu komunitas yang diakibatkan oleh ancaman bahaya baik secara sosial, fisik, ekonomi, juga lingkungan. Ancaman ( $\mathrm{H}=$ Hazard), adalah suatu kondisi berbahaya yang bisa menyebabkan hilangnya nyawa, cedera atau gangguan kesehatan lainnya yang dapat mengakibatkan rusaknya harta benda, hilangnya penghidupan dan layanan, tergangguannya aktivitas sosial dan ekonomi, atau kerusakan lingkungan. Kapasitas $\quad(\mathrm{C}=$ Capacity $) \quad$ adalah gabungan antara semua kekuatan, ciri yang melekat dan sumber daya yang tersedia dalam sebuah komunitas, masyarakat atau organisasi yang dapat digunakan untuk mencapai tujuan- tujuan yang disepakati (ASDRRN, 2010).

\section{Program Pengurangan Risiko Bencana}

Peraturan BNPB Nomor 4 tahun 2008 menjelaskan bahwa program pengurangan risiko bencana adalah upaya yang dapat dilakukan untuk mengurangi dampak yang ditimbulkan dari bencana. Secara spesifik, dalam memaksimalkan program ini, Pemerintah mengeluarkan Surat Edaran Kemendiknas No. 70a/MPN/SE/2010 tentang Pengarusutamaan Pengurangan Risiko Bencana di Sekolah. Dengan tindak lanjutnya, Kementrian Pemberdayaan Perempuan dan Perlindungan Anak melalui Deputi Tumbuh Kembang Anak juga menerbitkan petunjuk teknis atau panduan sekolah ramah anak, yang dalam komponennya terdapat poin 1) memiliki komitmen untuk menerapkan 
sekolah/madrasah aman dari bencana secara struktural dan non struktural dan 2) memastikan pengarusutamaan Pengurangan Risiko Bencana dalam proses pembelajaran

UNISDR (2005), memiliki lima prioritas pengurangan risiko bencana sebagai berikut:

a. Pengurangan Risiko Bencana harus menjadi program tingkat nasional dan menjadi prioritas lokal dengan dukungan lembaga yang kuat untuk mengimplementasikannya

b. Identifikasi, menilai, dan memonitor risiko bencana dan early warning system

c. Menggunakan pengetahuan, inovasi, dan pendidikan untuk membangu budaya aman dan resilience

d. Mengurangi faktor-faktor risiko

e. Memperkuat kesiapsagaan bencana untuk respon bencana yang efektif pada semua jenjang.

\section{Bencana Banjir}

Menurut Kurniasih \& Sukaesih (2017) banjir merupakan suatu bencana yang terjadi di wilayah yang memilik iklim dengan curah hujan yang tinggi dan tanah tidak dapat meresap air yang kemudian terjadi genangan air yang merugikan warga disekitarnya. Sebagai akibat terjadinya banjir, masyarakat dapat kehialangan harta benda, mengalamo gangguan psikologis, kesehatan, juga mungkin kehilangan nyawa (Rochman, Yulianti, Nasrudin, \& Malik, 2015; Kurniasih \& Sukaesih, 2017).

Dampak dari bencana banjir dapat dikurangi dengan adanya partisipasi aktif dari berbagai lapisan masyarakat. Peningkatan pengetahuan kebencanaan mengenai banjir sejak dini, pelatihan kesiapsiagaan bencana dari usia sekolah, dapat membentuk pemahaman bencana banjir dan resiliensi terhadap bencana banjir (Bosschaart, Kuiper, Schee, \& Schoonenboom, 2013; Farid, Mano \& Udo, 2012; Rochman, Yulianti, Nasrudin, \& Malik, 2015; Boon \&
Pagliano, 2015; Kortenkamp \& Basten, 2015).

Kesiapsiagaan dapat berupa belajar berenang, sanitasi, pengelolaan air bersih, membuang sampah pada tempatnya, dan kegiatan lainnya yang dapat mengurangi dampak bencana banjir. Dengan pemahaman bencana banjir, masyarakat dapat mencegah dan mengantisipasi bencana banjir, serta mengetahui apa yang harus dilakukan pada saat bencana banjir menyerang.

\section{METODE PENELITIAN}

Partisipan yang dilibatkan adalah Guru sebanyak 24 orang yang berasal dari 12 lembaga TK yang berada di kawasan rawan bencana di Dayeuhkolot kota Bandung. Adapun bencana yang sering dialami oleh partisipan adalah bencana banjir.

Metode yang digunakan adalah Participatory Action Research (PAR), yang dilaksanakan secara partisipatif dengan tujuan untuk mendorong terjadinya perubahan kondisi hidup partisipan yang lebih baik (Kemmis, McTaggart \& Nixon, 2014), dalam hal ini yaitu untuk meningkatkan pemahaman, kesadaran serta kemampuan guru dalam melakukan mitigasi bencana pada jenjang PAUD.

Pengumpulan data dilakukan melalui observasi dan wawancara dengan partisipan, kemudiaan diolah melalui teknik analisis tematik. Fereday \& Cochrane (2006) mengungkapkan bahwa analisis tematik adalah memberikan pelaporan dengan menekankan pada jawaban-jawaban atas pertanyaan penelitian, sehingga menghasilkan tematema pelaporan yang sesuai dengan pertanyaan penelitian, dalam kajian ini meliputi bentuk pelatihan dan capaian hasil pelatihan bagi guru TK.

Adapun pelaksanaan tindakan melalui Pelatihan Pengurangan Risiko Bencana bagi Guru TK di wilayah Dayeuhkolot kota Bandung meliputi tahapan pelaksanaan sebagai berikut: 


\section{Penentuan Tujuan}

Tahap Pertama, menentukan tujuan pelatihan yaitu untuk meningkatkan pemahaman dan kesadaran guru mengenai pentingnya kesiapsiagaan anak dalam menghadapi bencana alam.

\section{Penentuan Materi Pelatihan}

Tahap Kedua, menentukan materi yang akan diberikan kepada guru., dalam hal ini adalah materi

Pengurangan Risiko Bencana di Lembaga Pendidikan Anak Usia Dini.

Pelaksanaan Pelatihan

Tahap Ketiga, Melaksanakan peatihan berupa penyampaian materi, praktik dan feed back dari partisipan

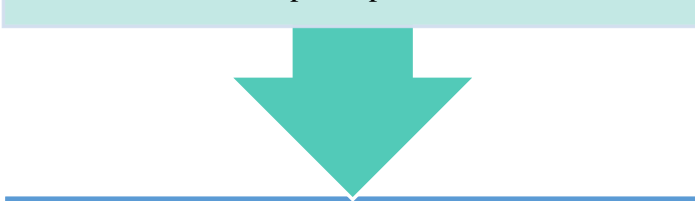

Evaluasi

Tahap Keempat, melakukan evaluasi terhadap ketercapaian Pelatihan Pengurangan Risiko Bencana bagi Guru di Lembaga Pendidikan Anak Usia Dini.

Gambar 1. Tahapan Pelaksanaan Pelatihan Pengurangan Risiko Bencana

\section{HASIL DAN PEMBAHASAN}

Hasil kajian ini meliputi gambaran terkait bentuk dan capaian pelatihan pengurangan risiko bencana banjir bagi guru TK. Adapun penjelasannya dapat diuraikan sebagai berikut:

\section{Bentuk Pelatihan Pengurangan Risiko Bencana pada Guru TK}

Pelatihan pengurangan risiko bencana bagi guru TK ini dilaksanakan pada tahun 2019, dengan melibatkan 24 orang guru dari 12 lembaga TK yang ada di kecamatan Dayeuhkolot Bandung dan merupakan masyarakat penyintas bencana banjir.

Pelatihan dilakukan sesuai dengan tahapan yang sudah direncanakan yaitu meliputi penentuan tujuan, penentuan materi, pelaksanaan dan evaluasi. Materi yang dikembangkan dalam kegiatan pelatihan ini antara lain sebagai berikut:

a. Pemahaman mengenai kebencanaan

b. Simulasi Guru Siaga Bencana

c. Pengembangan kebencanaan banjir di TK

d. Mengenal media siaga banjir (Tas Siaga, Poster, Puzzle, CD)

e. Mari menyusun dongeng dan lagu mengenai banjir

Tahap pelaksanaan pelatihan dilakukan dengan penyampaian materi dan praktik pengurangan risiko bencana banjir bagi jenjang PAUD, antara lain sebagai berikut:

a. Pemberian Materi Kebencanaan

Pada kegiatan ini guru diberikan pembekalan terkait konsep bencana dan permasalahan-permasalahan bencana yang muncul di Indonesia. Pada tahap ini juga guru diminta unruk mengungkapkan pendapatnya terkait bencana, khusunya bencana banjir yang dialami dan bagaimana guru menyikapi bencana tersebut di lembaga PAUD. Dokumentasi kegiatan tersebt antara lain sebagai berikut:

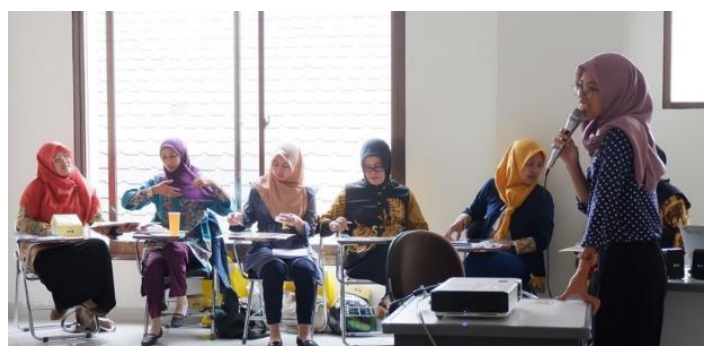

Gambar 2. Narasumber sedang menyampaikan Materi Kebencanaan pada guru TK 
b. Simulasi Guru Siaga Bencana

Guru diberikan kesempatan untuk melakukan simulasi kesiapsiagaan dalam menghadapi bencana meliputi simulasi dalam menghadapi bencana banjir, gempa dan lain sebagainya. Dokumentasinya antara lain sebagai berikut:

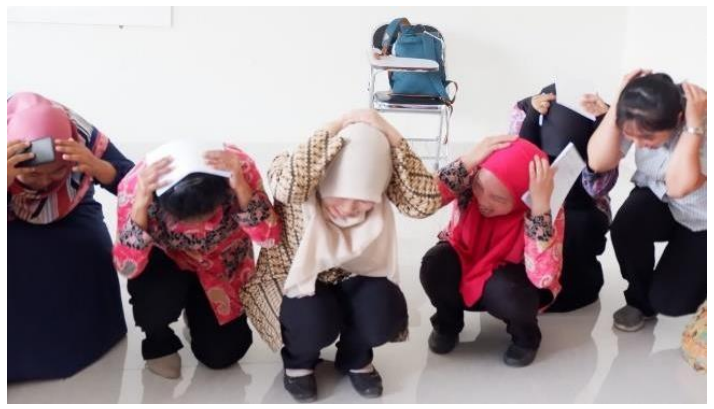

Gambar 3.Partisipan sedang Melakukan Simulasi ketika Menghadapi Bencana

c. Pengembangan pembelajaran kebencanaan banjir di TK

Pada kegiatan ini guru melakukan pengembangan dan menyusun perencanaan pembelajaran pengenalan kebencanaan banjir bagi anak usia dini. Dokumentasinya antara lain sebagai berikut:

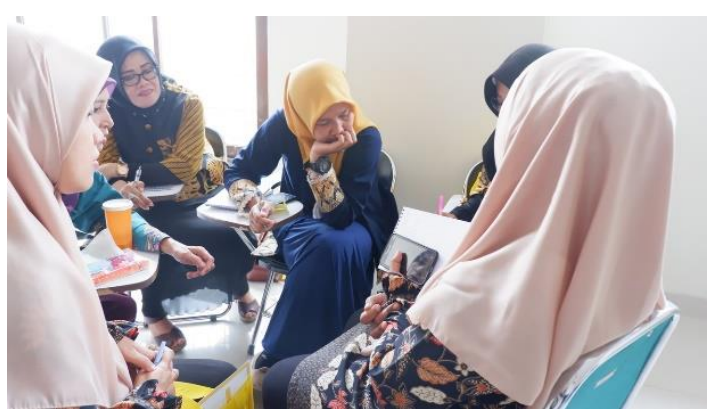

Gambar 4. Guru dan Narasumber Melakukan Pengembangan Pembelajaran Kebencanaan Banjir bagi Anak

d. Pengenalan Media Siaga Banjir (Tas Siaga, Poster, Puzzle, CD)

Pada tahap ini narasumber mengenalkan berbagai jenis media siaga banjir yang dapat dikenalkan pada anak yang meliputi Tas Siaga, Poster, Puzzle, CD. Dokumentasinya antara lain sebagai berikut:

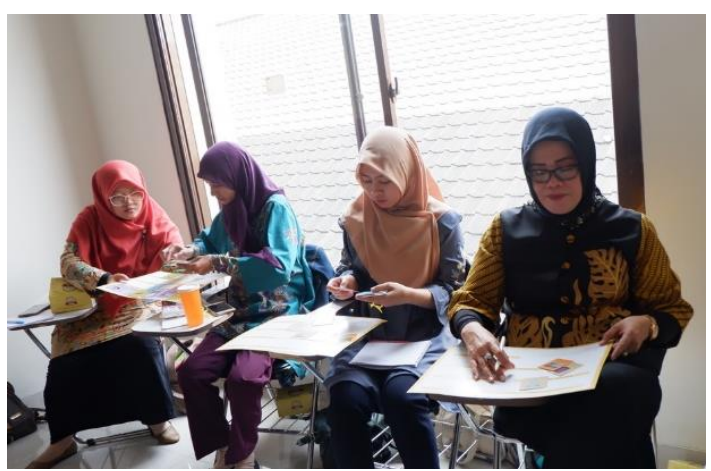

Gambar 5. Guru Melakukan Analisis Media Siaga Banjir berupa Poster

e. Praktik menyusun dongeng dan lagu mengenai banjir

Pada kegiatan ini guru melakukan praktik pembelajaran bagi anak usia dini terkait kebencanaan banjir dengan metode dongeng dan lagu. Dokumentasinya antara lain sebagai berikut:

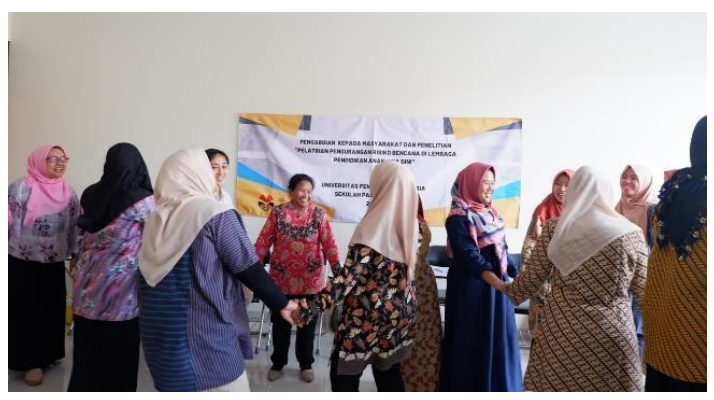

Gambar 3. Partisipan Mempraktikan

Pembelajaran Kebencanaan banjir bagi Anak melalui Gerak dan Lagu

Bentuk pelatihan yang telah dilakukan dalam kajian ini sejalan dengan kebijakan pemerintah melalui peraturan BNPB nomor 4 tahun 2008 mengenai Program Pengurangan Risiko Bencana yang menyatakan bahwa Program Pengurangan Risiko Bencana hendaknya merupakan tanggung jawab bersama termasuk diantaranya lembagalembaga yang bergerak dalam bidang pembangunan maupun lembaga-lembaga bantuan kemanusiaan dan harus menjadi bagian terpadu dari kerja-kerja organisasi.

Lebih lanjutn BNPB (2008) juga menyatakan bahwa program penanggulangan bencana membutuhkan 
penanganan kolektif yang melibatkan berbagai disiplin dan kelompok kelembagaan yang beragam dan menyeluruh sehingga dapat meningkatkan kesiapsiagaan masyarakat di daerah rawan bencana salah satunya dengan membekali informasi dan kompetensi dalam melakukan mitigasi bencana bagi masyarakat.

\section{Capaian Hasil Pelatihan Pengurangan Risiko Bencana Pada Guru TK}

Capaian hasil pelatihan pengurangan risiko bencana pada guru TK meliputi tiga aspek yaitu pemahaman dan kesadaran guru terkait pengurangan tisiko bencana di lembaga PAUD serta kemampuan guru dalam melakukan mitigasi bencana bagi anak usia dini. Gambaran mengenai hasil capaian ini dapat terlihat pada tabel sebagai berikut:

Tabel 1. Kondisi Awal, Kegiatan dan Capaian Hasil Pelatihan pada Guru TK

\begin{tabular}{|c|c|}
\hline \multicolumn{2}{|c|}{ a. Pemahaman Guru terkait Bencana } \\
\hline Kondisi & $\begin{array}{c}\text { Guru sudah memiliki } \\
\text { pemahaman terkait bencana, } \\
\text { khususnya bencana banjir dan } \\
\text { faktor yang mempengaruinya. } \\
\text { Adapun yang masih belum } \\
\text { dipahami secara mendalam } \\
\text { oleh guru adalah terkait } \\
\text { konsep pengurangan risiko } \\
\text { bencana pada anak usia dini } \\
\text { di kawasan banjir, khusunya } \\
\text { informasi apa saja yang perlu } \\
\text { disiapkan ketika menghadapi } \\
\text { banjir dan bagaimana } \\
\text { mengenalkannya pada anak. }\end{array}$ \\
\hline Kegiatan & $\begin{array}{c}\text { Pelatihan: Materi } \\
\text { Kebencanaan dan Media } \\
\text { Siaga Banjir }\end{array}$ \\
\hline Hapaian & $\begin{array}{c}\text { Guru mendapatkan } \\
\text { informasi yang lebih } \\
\text { komprehensif terkait }\end{array}$ \\
& $\begin{array}{c}\text { pengurangan risiko bencana } \\
\text { pada anak usia dini di } \\
\text { kawasan banjir. }\end{array}$ \\
\hline
\end{tabular}

\begin{tabular}{|c|c|}
\hline & $\begin{array}{l}\text { Berdasarkan hasil evaluasi, } \\
\text { guru menyampaikan bahwa } \\
\text { semakin memahami terkait } \\
\text { apa itu bencana banjir dan } \\
\text { penyebabnya, serta apa yang } \\
\text { perlu disiapkan dalam } \\
\text { meghadapi bencana banjir } \\
\text { tersebut khsusunya dalam } \\
\text { lingkup PAUD. }\end{array}$ \\
\hline \multicolumn{2}{|c|}{$\begin{array}{l}\text { b. Kesadaran Guru terkait Mitigasi } \\
\text { Bencana }\end{array}$} \\
\hline $\begin{array}{l}\text { Kondisi } \\
\text { Awal }\end{array}$ & $\begin{array}{l}\text { Guru belum memiliki } \\
\text { kesadaran mendalam tentang } \\
\text { pentingnya pengurangan } \\
\text { risiko bencana pada anak usia } \\
\text { dini dikawasan rawan banjir. } \\
\text { Guru memandang bahwa } \\
\text { konsep bencana banjir hanya } \\
\text { perlu dikenalkan secara } \\
\text { umum saja karena mengingat } \\
\text { usia anak yang masih dini } \\
\text { tanpa perlu dibekali terkait } \\
\text { kesiapsiagaan dalam } \\
\text { menghadapi bencana. }\end{array}$ \\
\hline Kegiatan & $\begin{array}{l}\text { Pelatihan: Materi } \\
\text { Kebencanaan }\end{array}$ \\
\hline $\begin{array}{l}\text { Capaian } \\
\text { Hasil }\end{array}$ & $\begin{array}{l}\text { Berdasarkan hasil evaluasi, } \\
\text { guru menyampaikan } \\
\text { semakin memiliki } \\
\text { kesadaran mengenai } \\
\text { pentingnya pengurangan } \\
\text { risiko bencana di lembaga } \\
\text { PAUD, khususnya terkait } \\
\text { kesiapsiagaan anak dalam } \\
\text { menghadapi bencana alam } \\
\text { banjir/pengenalan mitigasi } \\
\text { bencana sejak dini dengan } \\
\text { berbagai metode } \\
\text { pembelajaran yang sesuai } \\
\text { dengan perkembangan } \\
\text { anak. }\end{array}$ \\
\hline \multicolumn{2}{|c|}{$\begin{array}{l}\text { c. Kemampuan Guru dalam Melakukan } \\
\text { Mitigasi Bencana }\end{array}$} \\
\hline $\begin{array}{l}\text { Kondisi } \\
\text { Awal }\end{array}$ & $\begin{array}{l}\text { Guru mengungkapkan } \\
\text { bahwa pengenalan banjir } \\
\text { pada anak dilakukan dalam } \\
\text { pembelajaran saat tema } \\
\text { alam semesta, sub tema } \\
\text { bencana alam. Pengenalan } \\
\text { bencana banjir baru terbatas }\end{array}$ \\
\hline
\end{tabular}




\begin{tabular}{|c|c|}
\hline & $\begin{array}{c}\text { dilakukan melalui bercerita } \\
\text { dan tanya jawab. }\end{array}$ \\
\hline Kegiatan & $\begin{array}{c}\text { Simulasi, Praktik } \\
\text { Pengembangan } \\
\text { Pembelajaran, Penyusunan } \\
\text { Dongeng dan Lagu }\end{array}$ \\
\hline $\begin{array}{l}\text { Capaian } \\
\text { Hasil }\end{array}$ & $\begin{array}{c}\text { Guru mampu melakukan } \\
\text { simulasi dalam menghadapi } \\
\text { bencana alam, salah satunya } \\
\text { banjir yang dapat } \\
\text { dikenalkan pada anak usia } \\
\text { dini. Selain itu, guru juga } \\
\text { mampu melakukan } \\
\text { pengembangan } \\
\text { pembelajaran terkait } \\
\text { kebencanaan, melakukan } \\
\text { praktik menyusun dongeng } \\
\text { dan lagu pengenalan } \\
\text { bencana bagi anak usia dini. }\end{array}$ \\
\hline
\end{tabular}

Berdasarkan data di atas, pelatihan yang diberikan mendapatkan hasil yang cukup positif yaitu semakin meningkatkan pemahaman, kesadaran serta kemampuan guru dalam melakukan mitigasi bencana pada jenjang PAUD. Hal tersebut sesuai dengan konsep yang diuraikan oleh UNISDR (2005) bahwa salah satu prioritas pengurangan risiko bencana dapat ditempuh dengan menggunakan pengetahuan, inovasi, dan pendidikan untuk membangu budaya aman dan resilience serta memperkuat kesiapsagaan bencana untuk respon bencana yang efektif pada semua jenjang.

BNPB (2016) juga
menggambarkan bahwa bahwa mitigasi bencana hendaknya diberikan pada setiap warga, termasuk anak, bukan hanya mengenalkan apa itu bencana banjir namu juga sudah lebih luas terkait dengan apa yang harus dilakukan ketika bencana banjir terjadi. Pemberian pengetahuan terkait hal tersebut diharapkan dapat mengurangi faktor risiko atau dampak dari bencana banjir itu sendiri. Informasi lain yang diperoleh dari partisipan yaitu tidak terdapatnya nomor darurat bencana di lembaga/sekolah, khususnya di lembaga PAUD.

\section{KESIMPULAN}

Pelatihan Pengurangan Risiko Bencana merupakan suatu kegiatan yang dilaksanakan untuk mengidentifikasi, memberikan wawasan dan memberikan keterampilan dalam kaitan pengurangan risiko bencana. Pelatihan ini bertujuan untuk mengurangi kerentanan-kerentanan yang dapat mengganggu stabilitas sosialekonomi dari suatu bencana, khususnya pada lembaga PAUD.

Pelatihan pengurangan risiko bencana bagi guru TK di Kota Bandung diharapkan dapat meningkatkan kesiapsiagaan guru dalam mengantisipasi kemungkinan terjadinya bencana guna menghindari jatuhnya korban jiwa, kerugian harta benda dan berubahnya tata kehidupan masyarakat. Kesiapsiagaan guru TK dalam menghadapi bencana juga diharapkan dapat menghindari jatuhnya korban anak usia dini dengan mempersiapkan anak-anak untuk dapat membantu dirinya sendiri dan orang lain ketika terjadi bencana banjir.

Adapun rekomendasi kajian selanjutya adalah pengembangan panduan mitigasi bencana bagi anak usia dini yang dapat dijadikan acuan secara nasional bagi guru dalam menstimulasi kesiapsiagaan bencana alam khususnya di lembaga PAUD.

\section{DAFTAR PUSTAKA}

Aghaei, N., Seyedin, H., \& Sanaeinasab, H. (2018). Strategies for Disasater Risk Reduction Education: A Systematic Review. Journal of Education and Health Promotion.

ASEAN Disaster Risk Management Initiative. (2010). Synthesis Report on Ten ASEAN Countries Disaster Risks Assessment.

BNPB, 2016. Pendidikan dan Pelatihan Penanggulangan Bencana. Jakarta: BNPB. 
Boon, H. J., \& Pagliano, P. J. (2015). Disaster Education in Australian Schools. Australian Journal of Environmental Education, 30(2), 187-197.

Bosschaart, A., Kuiper, W., Schee, J. v., \& Schoonenboom, J. (2013). The role of knowledge in students' flood-risk perception. Natural Hazards, 69(3), 1661-1680.

Farid, M., Mano, A., \& Udo, K. (2012). Urban Flood Inundation Model for High-Density Building Area. Journal of Disaster Research, 7(5), 554-559.

Fereday, J \& Cochrane, E.M. (2006). Demonstrating rigor using thematic analysis: A hybrid approach of inductive and deductive coding and theme development. International Journal of Qualitative Methods, 5 (1), hlm. 1-11.

Haynes, K., Ronan, K., Bird, D. K., Towers, B., \& Amri, A. (2017). Disaster risk reduction education in Indonesia: challenges and recommendations for scaling up. Natural Hazards and Earth System Sciences, 17(4), 595-612. https://doi.org/10.5194/nhess-17595-2017.

Kemendiknas No. 70a/MPN/SE/2010 tentang Pengarusutamaan Pengurangan Risiko Bencana di Sekolah.

Kemmis, McTaggart \& Nixon. (2014). The Action Reserach Planner: Doing Critical Participatory Action Research. New York: Springer.

Kortenkamp, K. V., \& Basten, B. (2015). Environmental Science in the Media_Effects of Opposing Viewpoints on Rosk and Uncertainty Perceptions. Science Communication, 1-27.

Kurniasih, N., \& Sukaesih. (2017). Public Health Information
Behavior at Flood-Prone Area In Bandung Regency: A Case Study in Baleendah Village, Andir Village, Bojongsoang Village and Dayeuh Kolot Village. Record and Library Journal, 3(1), 1-9.

Peek, L., Abramson, D. M., S.Cox, R., Fothergill, A., \& Tobin, J. (2018). Children and Disaster. Springer, 243-261.

Peraturan BNPB Nomor 4 tahun 2008 tentang Pedoman Penyusunan Rencana Penanggulangan Bencana.

Rochman, C., Yulianti, R. N., Nasrudin, D., \& Malik, A. (2015). Physics concept on flood mitigation in West Java. 3rd Annual Applied Science and Engineering Conference (AASEC 2018). Bandung: IOP Publishing.

Thomas, Phillips, Lovekamp, \& Fothergill, 2013. Social Vulnerability to Disasters ${ }^{2 n d}$ Edition. US: CRC Press.

Undang-Undang No. 24 Tahun 2007 Tentang Penanggulangan Bencana.

UNISDR (2009). Terminology on Disaster Risk Reduction. Geneva: United Nation. 